\title{
THE DESIGN AND FABRICATION OF A COMPOUND DIE TO
}

\author{
MAKE HEXAGONAL WASHER \\ N. JYOTHIRMAYI ${ }^{1} \&$ DR. B. V. S. RAO ${ }^{2}$

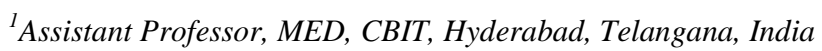 \\ ${ }^{2}$ Assistant Professor, CBIT, Hyderabad, Telangana, India
}

\begin{abstract}
Many parts and components used in mechanical industry are manufactured by cold pressing operations. Die is the main tool in these operations. There are different types of dies like progressive die, compound die and combination die.

This paper presents design and fabrication of a compound die which combines blanking and piercing operations. Design and development of compound die is one of the important phases in sheet metal working. The small error in the design can result in heavy manufacturing losses through die failure, part geometry distortion and production risk. Assembly of all the die elements is another task where use of accurate measuring instruments for alignment of various tool elements is important. In the present work, a compound die for production of a hexagonal washer of M15 bolt has been designed and developed. The 2D modelling of the compound die has been done using solid works software. This press tool has been tried out on a fly press. The components produced are to the required dimensions.

KEYWORDS: Cold Pressing, Progressive Die, Compound Die, Combination Die, Blanking, Piercing, Solid works \& Fly Press
\end{abstract}

Received: May 10, 2019; Accepted: Jun 02, 2019; Published: Jul 03, 2019; Paper Id.: IJMPERDAUG201951

\section{INTRODUCTION}

Sheet metal working is an important manufacturing process for many industries producing kitchen utensils, home appliances, electronics, automobiles, toys, furniture etc. Most of these products have sheet metal casings that are made by cutting and forming the sheet metal. Some of the basic sheet metal operations are blanking, punching (Piercing), drawing and bending.

Blanking is a cutting process in which a piece of sheet metal is removed from a larger piece of stock by applying required shearing force. In this process, the piece removed, called the blank, is not scrap but rather the desired part. Blanking can be used to cutout parts in almost any $2 \mathrm{D}$ shape, but is most commonly used to cut work pieces with simple geometries that will be further shaped in subsequent processes. Punching is a process in which the punch removes a portion of material from the larger piece or a strip of sheet metal. If the small removed piece is discarded, the operation is called punching, Figure 1 shows difference between blanking and piercing, 

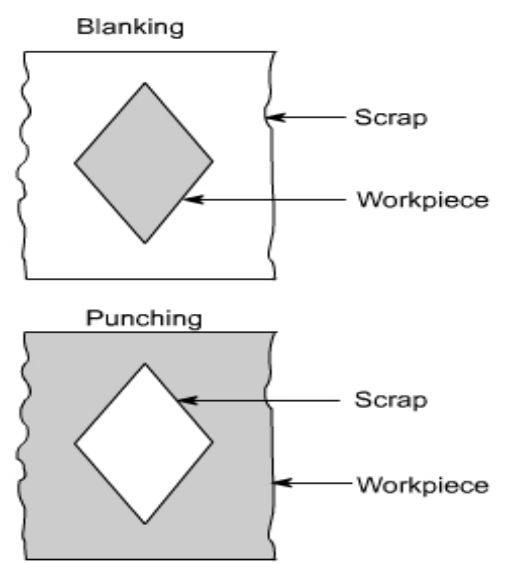

Figure 1: Blanking Vs Piercing Operations

Die is the main tool used for these press working operations. It is a specialized tool used to cut or shape materials into pre-determined shapes. There are different types of dies- simple die, progressive die, compound die and combination die.

Simple die performs only one operation like blanking or punching or drawing etc. The die which performs two or more operations simultaneously at different work stations in a single stroke is known as a progressive die. Compound die performs two or more cutting operations, typically piercing and blanking at single station in single press cycle. The advantage of a compound die is the high and unsurpassed mechanical accuracy of a single step process.

Die design is an important part of press metal working. Many parameters have to be considered while designing the dies for various sheet metal working operations. The construction of compound die is more complicated than progressive die. A common characteristic of compound-die design is the inverted construction, with the blanking die on the upper die shoe and the blanking punch on the lower die shoe. Figure 2 shows the compound die assembly and its various parts.

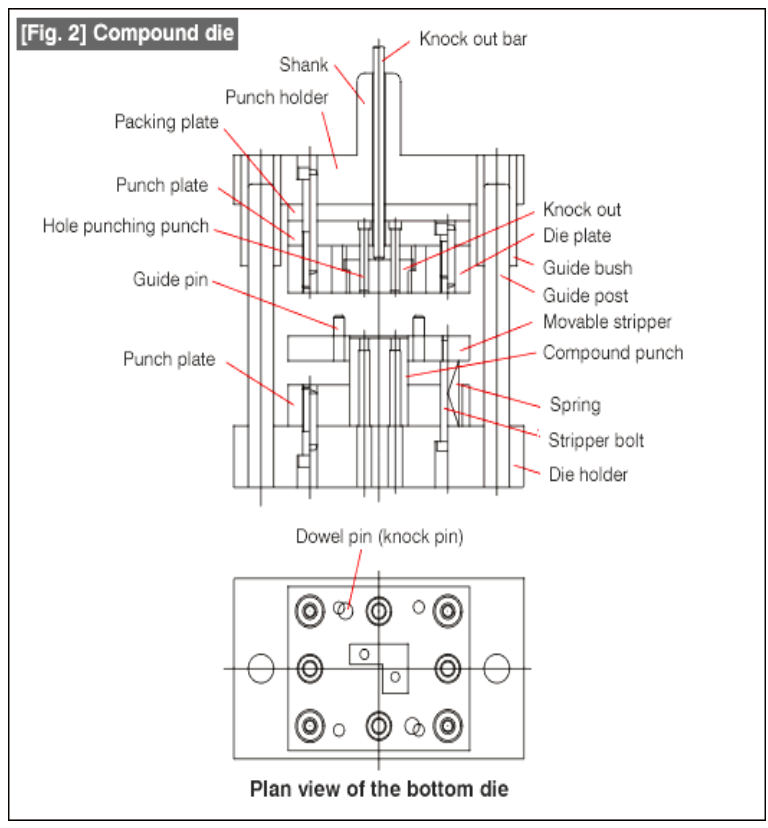

Figure 2: Compound Die Assembly 
In this paper a compound die combining blanking and punching operations is designed and fabricated to make a hexagonal washer of M15 bolt. 2D modeling is done using SOLIDWORKS software.

\section{METHODOLOGY}

Figure 3 shows a simple component called hexagonal washer for which a simple compound die needs to be designed.

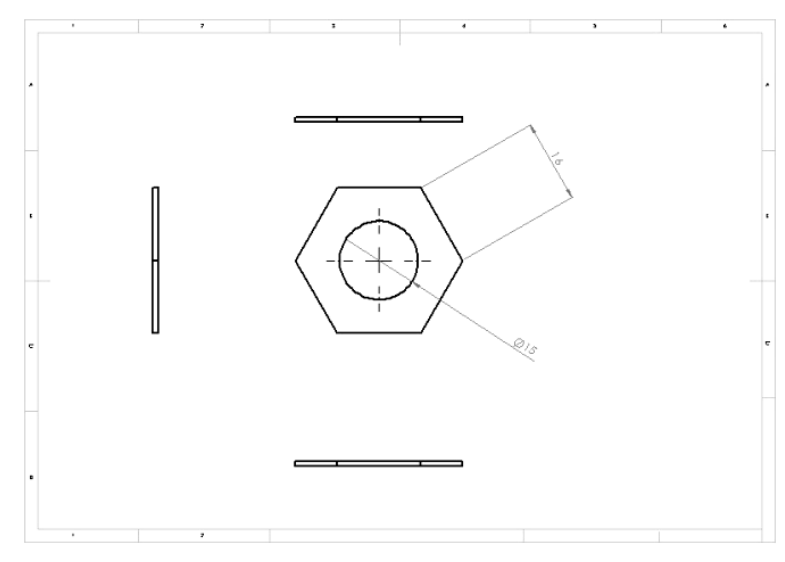

Figure 3: Hexagonal Washer to be Made

The specifications of washer to be made are given in the table 1.

Table 1: Specifications of Washer

\begin{tabular}{|c|l|l|}
\hline S. NO & \multicolumn{1}{|c|}{ Description } & \multicolumn{1}{c|}{ Specification } \\
\hline 1 & Component name & hexagonal washer \\
\hline 2 & Type of tool & compound tool \\
\hline 3 & Sheet metal material & mild steel \\
\hline 4 & Sheet thickness & $1 \mathrm{~mm}$ \\
\hline 5 & Press tonnage & 8 tons \\
\hline
\end{tabular}

\section{Design of Compound Die}

As far as sheet metal working is concerned, the die design is a very important aspect. Many parameters have to be considered while designing the dies for various sheet metal working operations.

\section{Selection of Materials}

Press tools are generally made using $\mathrm{HCHCr}$, Steel alloys with high carbon. But before that based on many factors like cost, strength, hardness, strain and many parameters selection should be made. The materials used are D2, EN31. Mild Steel is used as supporting plate. Apart from that, materials like the D3, high carbide materials, chromium steels and high speed steels are also used.

\section{Design and Optimization of Punch and Die}

Some thumb rules and standards are used for die and punch size calculation. The force required for blanking and punching is also calculated. Optimization is carried out by selecting different materials for die and punch. By selecting different material for die and punch we get a variety of choices for choosing particular material. On the basis of properties of different material we will optimize the specific material for die and punch. 


\section{Calculation of Press Capacity}

We have press capacity $=$ Fmax $* \mathrm{C}$

Where $\mathrm{C}=1.1$ to 1.5 for normal profile

$$
\mathrm{C}=1.25 \text { to } 1.75 \text { for } \frac{d}{t}<2
$$

Presscapacity $=$ Fmax $* \mathrm{C}$

$$
\begin{aligned}
& =8 \text { tons } * 9.81 * 1.5 \\
& =8 * 1000 * 9.81 * 1.5 \\
& =11720 \mathrm{~N}
\end{aligned}
$$

Energy of press $=$ Fmax $* C^{*}$ punch travel

$$
\begin{aligned}
& =8000 * 9.81 * 1.5 * 8 \\
& =94176 \quad \mathrm{~N}-\mathrm{m}
\end{aligned}
$$

\section{Minimum Diameter of Piercing}

We have piercing pressure $=(T)^{*} \pi * d$ l strength of the punch $=\sigma * \pi \frac{d^{\wedge} \mathbf{2}}{4}$

If we equate the piercing and strength of the punch we obtain the minimum diameter of piercing

$\operatorname{ie}(7) * \pi * \mathrm{dl}=\sigma * \pi \frac{d^{2}}{4}$

$\mathrm{d}=\frac{(T)}{\sigma} 4 * \mathrm{t}$

$\mathrm{d}=2 \mathrm{t}(\sigma=2 \tau)$

as our compound die piercing punch diameter is 15

so it si safe

ie $\quad 15 \mathrm{~mm}>2 \mathrm{t}$

$15 \mathrm{~mm}>2 \mathrm{~mm}$

Minimum size of punched holes depending upon their shapes are as follows:
0.7 to $1.2 \mathrm{t}$ for soft steel
0.9 to $1.5 \mathrm{t}$ for steel
1.75 to $2 \mathrm{t}$ for $\mathrm{Ti}$ alloys
0.6 to $0.9 \mathrm{t}$ for brass and copper
0.5 to $0.8 \mathrm{t}$ for zinc
0.4 to $0.7 \mathrm{t}$ for Bakelite 
0.3 to $0.6 \mathrm{t}$ for cardboard and paper

\section{Die Block Thickness}

Die block thickness can be calculated as follows

Die block thickness $=\mathrm{T}=\sqrt[3]{F}$ where $\mathrm{F}$ is in tons

$$
=\sqrt[3]{8}=2 \mathrm{~mm}
$$

die block thickness is taken as $20 \mathrm{~mm}$

\section{Relief Angle}

As already mentioned relief angle should be $\frac{10}{4}$ to $1^{0}$ for small die

$1^{0}$ to $2^{0}$ for average die

$2^{0}$ to $3^{0}$ for large die

As our compound die is average die relief angle should be between $1^{0}$ and $2^{0}$

So relief angle for die is equal to $\tan ^{-1} \frac{1}{40}$

$=1.432$ so it is between $1^{0}$ to $2^{0}$

\section{Area of Die Opening Border}

Table 2: Area of Die Opening Border

\begin{tabular}{|c|c|}
\hline $\begin{array}{c}\text { Maximum Cutting } \\
\text { Force (KN) }\end{array}$ & $\begin{array}{c}\text { Area between Die } \\
\text { Opening Border }\left(\mathbf{c m}^{\mathbf{2}}\right)\end{array}$ \\
\hline 200 & 3.25 \\
\hline 500 & 6.5 \\
\hline 750 & 9.75 \\
\hline 1000 & 13.00 \\
\hline
\end{tabular}

Area of die opening border for various cutting forces are shown in the table 2 .

\section{Fastening of Die Block}

Screw diameter $=0.5 \mathrm{t}$ for $\mathrm{T}<19 \mathrm{~mm}$

$=0.4 \mathrm{t}$ for $\mathrm{T}>19 \mathrm{~mm}$

We took it as $8 \mathrm{~mm}$ which is greater than $0.4 \mathrm{t}$ for the sake of safety and alignment purpose

\section{Punch Length}

Maximum length of punch is equal to

$$
\begin{aligned}
\mathrm{L} & =\frac{\pi d}{8} \operatorname{sqrt}\left(\frac{E d}{\tau t}\right) \\
& =\frac{\pi * 15}{8} \operatorname{sqrt}\left(\frac{2 * 100000 * 15}{400}\right) \\
& =510 \mathrm{~mm}
\end{aligned}
$$


But generally punch length is taken as 60 to $85 \mathrm{~mm}$. So $64 \mathrm{~mm}$ is taken as length of the punch.

\section{Design of Spring}

Maximum force on spring is should be as follows

Fmax $>1.5 * \frac{F s t r}{i}(\mathrm{i}=1)$

Where Fstr=stripper force

$=0.05$ to $0.08 * \mathrm{~F}$

$=0.07 * 8000$

$=5493.6 \mathrm{~N}$

$\mathrm{Fmax}=1.5 * \frac{5493.6}{1}=8240.4$

Fmax $=8240.6 \mathrm{~N}$.

\section{Calculation of Punching Force and Blanking Force}

\section{Punching}

Punch size $=15 \mathrm{~mm}+$ allowances

$$
\begin{aligned}
& =15+0.05 \\
& =\mathbf{1 5 . 0 5} \mathbf{m m}
\end{aligned}
$$

Die size $=$ punch size $+2 \mathrm{c}$

Where $\mathrm{c}$ is clearance

$=15.05+2$

$=15.25 \mathrm{~mm}$

Punching force $=\pi \mathrm{dt} \tau$

Where $\mathrm{d}$ is diameter of punch

$t$ is thickness of metal sheet

$\tau$ is shear force

punching force $=\pi * 15.05 * 1 * 400$

$=18912.38 \mathrm{~N}$

\section{Blanking}

Blanking force=perimeter $*$ thickness $*$ shear force

$=($ perimeter of hexagonal-perimeter of

circle)*thickness*shear force 
Make Hexagonal Washer

$$
\begin{aligned}
& =(6 * \text { side of hexagon }-\pi \mathrm{d}) * 1 * 400 \\
& =(6 * 16-\pi * 15) * 400 \\
& =48.876 * 400 \\
& =19550.44 \mathrm{~N}
\end{aligned}
$$

\section{Modeling of the Compound Die}

The 2D modeling of the die is made using

\section{Solid Works}

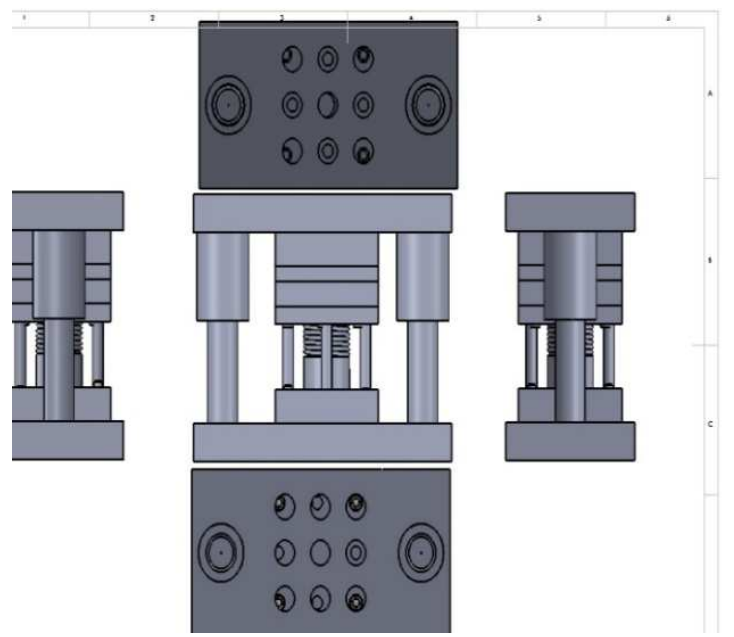

Figure 4: 2D Model of Compound Die

The five views of compound die in the first angle projection are shown in the figure4.

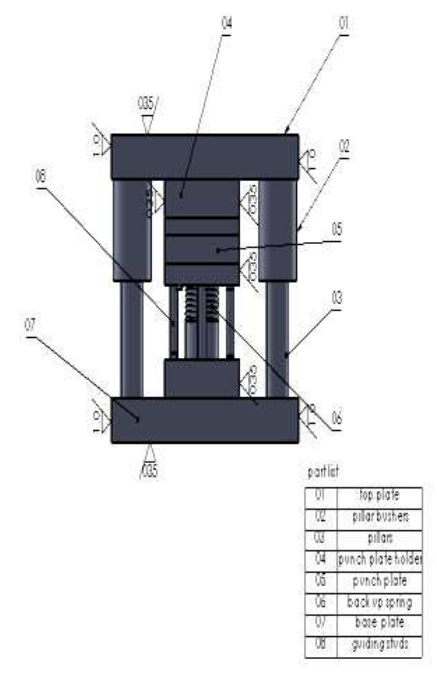

Figure 5: Surface Roughness Values and Parts List

Parts list and surface roughness values are shown in the figure5. 
Fabrication of Compound Die

Operations carried for each part are shown below:

\section{Top Plate}

- $\quad$ Milling

- $\quad$ Bench work

- Drilling

- $\quad$ Surface grinding

\section{Base Plate}

- $\quad$ Milling

- $\quad$ Bench work

- Drilling

- $\quad$ Surface grinding

\section{Guide Bushes}

- $\quad$ Turning

- Cylindrical grinding

- Heat treatment

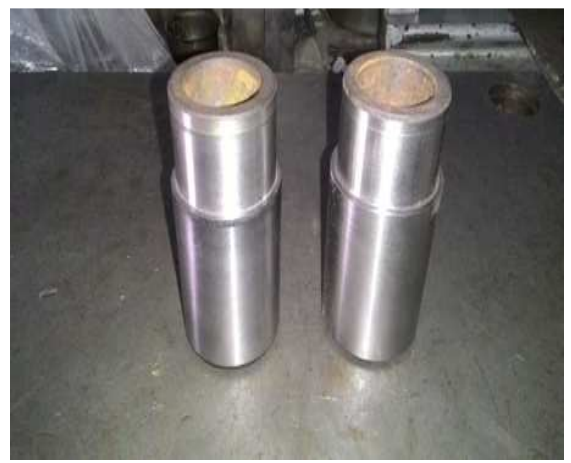

Figure 6: Guide Bushes

\section{Guide Pillars}

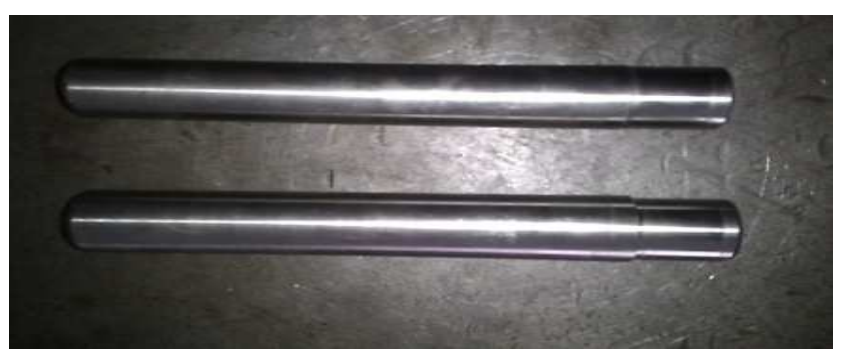

Figure 7: Guide Pillars 
- $\quad$ Turning

- Cylindrical grinding

- Heat treatment

Guide bushings and guide pillars shown in figure 6 and figure 7 are not only useful for aligning the die members but also reduce the die setup time.

\section{Punch Holder}

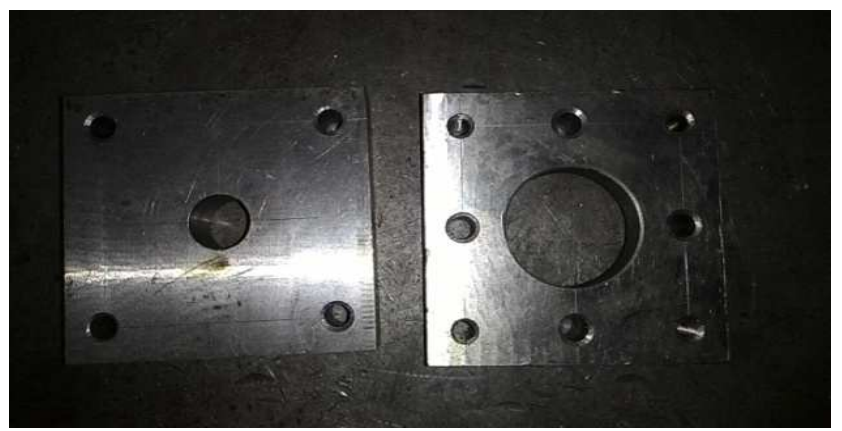

Figure 8: Punch Holder

- Milling

- Bench work

- $\quad$ Surface grinding

- $\quad$ CNC milling

\section{Die Plate}

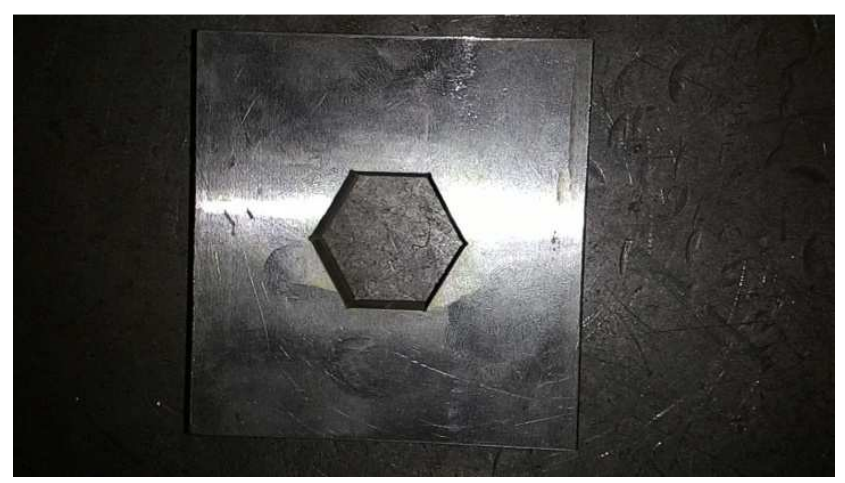

Figure 9: Die Plate

- Milling

- Bench work

- Drilling

- $\quad$ Surface grinding

- Heat treatment 
- $\quad$ CNC milling

Punch holders and die plate are shown in figure 8 and figure 9.

\section{Back Plates}

- $\quad$ Milling

- $\quad$ Bench work

- Drilling

- $\quad$ Surface grinding

\section{Blanking Punch}

- $\quad$ Lathe

- Cylindrical grinding

- $\quad$ Profile grinding

- Heat treatment

\section{Piercing Punch}

- Lathe

- Cylindrical grinding

- $\quad$ Profile grinding

- Heat treatment

\section{Selection of Press and Testing of the Die}

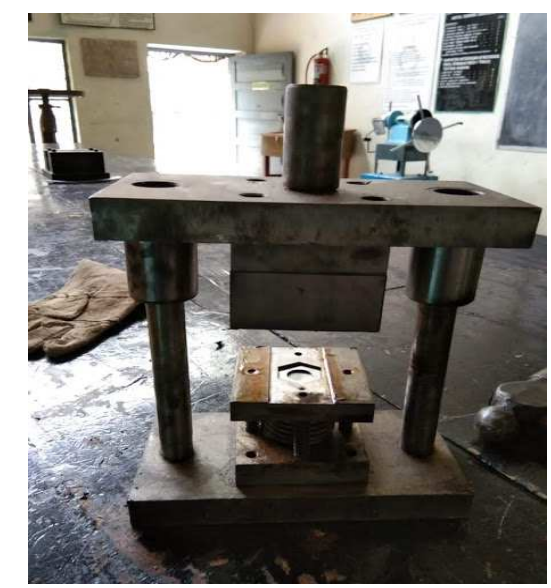

Figure 10: Compound Die Set

The fabricated compound die set shown in the figure 10 has been tested on a press.

The selection of suitable press depends upon various parameters. The following factors are considered while selecting the press: 
- Force required to cut the metal

- Stroke length

- Size and type of die

- Method of feeding and size of sheet blank

- Shut height

- Type of operation

Table 3: Blanking and Punching Forces

\begin{tabular}{|l|c|}
\hline Punch force & 16742.8 \\
\hline Die block thickness & $20 \mathrm{~mm}$ \\
\hline Punch length & $64 \mathrm{~mm}$ \\
\hline Punching: & \\
\hline Punch size & $15.05 \mathrm{~mm}$ \\
\hline Die size & $15.25 \mathrm{~mm}$ \\
\hline Punching force & $18912.38 \mathrm{~N}$ \\
\hline Blanking force & $19550.44 \mathrm{~N}$ \\
\hline
\end{tabular}

Table 3 shows the sizes of punch \& die and blanking \&punching forces which are considered while selecting the press.

A fly press of suitable capacity shown in the figure 11 is selected for testing the die.

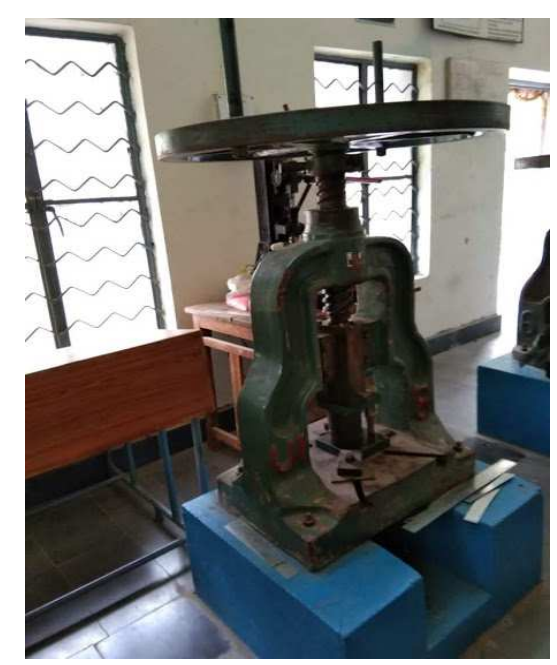

Figure 11: Fly Press used for Testing the Compound Die

The hexagonal washer shown in the figure 12 is produced successfully by the compound die on a fly press. 


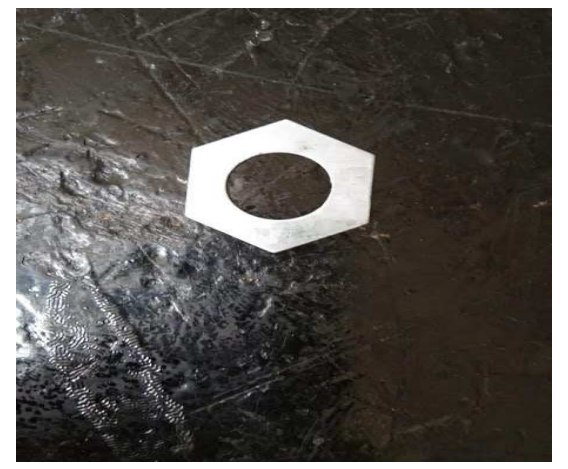

Figure 12: Hexagonal Washer Made

\section{CONCLUSIONS}

Compound die for the required hexagonal washer is designed, fabricated and tested successfully on a fly press of suitable capacity. The hexagonal washer made on the die is to the accurate dimensions. This die is being used successfully in the Metal forming Lab of Chaitanya Bharathi Institute of Technology, Hyderabad.

\section{REFERENCES}

1. David A. Smith, die design handbook, 3rd edition, chapter 27, Press Data.

2. David A. Smith, die design handbook, 3rd edition, chapter 4, Shear Action in Metal Cut.

3. G. R. Nagpal, Tool Engineering and Design, Press Tool Design.|

4. http://seminarprojects.com/Threaddesign-andmanufacturing-of-a-compound-tool.

5. Cyril Donaldson, George H LeCain, V C Goold, Tool design 3rd edition, Tata McGraw-Hill Education.

6. P H Joshi, “Jigs and fixtures” Tata McGraw-Hill Education, 2010

7. Dr. M. Venkateswara Rao, "Design and Analysis of Progressive Tool". International Journal of Engineering Research \& Technology (IJERT) Vol. 1 Issue 6, August- 2012

8. Vishwanath M. C., Design of Progressive Draw Tool". International Journal of Scientific and Research Publications, Volume 3, Issue 8, August 2013, ISSN 2250-3153

9. Rupali Chavan, Navneet Patil, Design, Development and Analysis of Press Tool for an Industrial Part", International Journal of Mechanical and Industrial Technology, 2016, pp.4-9.

10. Nireekshana, T. \& Ramesh Babu, V. (2017). Design and Fabrication of Linear Induction Motor For Traction Application. International Journal of Electrical and Electronics Engineering (IJEEE), 6(6), 1-18.

11. B. F. Satpute, M. S. Harne, „Design and Development of Compound Die for Bearing Cap“ International Journal of Recent Engineering Research and Development (IJRERD) Volume No. 02 - Issue No. 01, ISSN: 2455-8761 June- 2016, pp. 50-61. 